\title{
ANALYSIS OF FACTORS INFLUENCING GREEN PURCHASE BEHAVIOR: A CASE STUDY OF THE COSMETICS INDUSTRY IN INDONESIA
}

\author{
Nicholas Wilson, Evan Theodorus, Pauline Tan \\ Fakultas Ekonomi, Universitas Tarumanagara Jakarta \\ Email:wp8989@yahoo.com \\ Fakultas Ekonomi, Universitas Pelita Harapan Tangerang \\ Email: evan.theodorus@gmail.com \\ Fakultas Ekonomi, Universitas Pelita Harapan Tangerang \\ Email: pauline.henriette@uph.edu
}

\begin{abstract}
This research attempted to uncover factors which could influence consumer's green purchase behavior towards green cosmetic product in the Indonesian cosmetics Industry. Survey method was used in this research, in which questionnaires were distributed to 260 respondents who have ever bought and used green cosmetics products in Indonesia. Data were then analyzed using AMOS 22.0. Based on the results obtained in this research, it was concluded that attitude towards the behavior and perceived behavioral control had a positive impact on behavioral intention, while perceived behavioral control also had a positive impact toward consumers' green purchase behavior. Meanwhile, behavioral intention didn't have a positive impact on green purchase behavior. In regards to the value or implication generated in this research, the results of this research will improve academicians, practicioners, and public's knowledge and understanding about the factors which had a positive relationship or impact on Indonesian consumers' green purchase behavior in the cosmetics industry.
\end{abstract}

Keywords: green purchase behavior, attitude toward behavior, perceived behavioral control, behavioral intention, Indonesia cosmetics industry.

\section{INTRODUCTION}

In the $21^{\text {st }}$ century, environmental issues have been a concern to the world. The Earth Summit conference (1992) then held by United Nations in Rio de Janeiro, Brazil, to help the government rethink economic development and find ways to reduce or relieve the destruction of irreplaceable natural resources and pollution of the planet. The term "green" is then become popular in the world.

Green business is introduced to the world in the end of $20^{\text {th }}$ century to increase public awareness to the environmental problem. Green businesses are just like any other business that generates profits, but the difference lies on its concern, where it requires stability between profit, sustainability, and humanity. This concept or paradigm is attached to the word "green" as its concern of a sustainable environment. Procter and Gamble defines sustainable as acting in ways that ensures the better quality of life in the future of the next generation (Schermerhorn, 2013). Sometimes people are misinterpreting the concept green business with corporate social responsibility (CSR). CSR is one of many concept that a company done in order to balance the activity between profit, sustainability, and humanity. Environmentally raw materials, environmentally products, environmentally friendly technology, and a proper waste treatment are indicators of the green industry reward. Therefore, industries that participating in this event is appreciated because they have voluntarily apply green industry on their economic activities. The numbers of green rewards have been increasing since the first time this reward is held. This 
indicates that there are many companies or organizations which are starting to join a green industry to achieve a sustainable development.

This research studies the main factors influencing the green purchase behavior towards green cosmetic product, since the increasing numbers of company that promoting green cosmetic product in order to achieve a sustainable environment. In this research, the influencing factors are measured by referring to the previous research conducted by Mun (2014). Moreover, this study was also conducted in order to fill the gap existed in the previous research by Mun (2014), in which, Mun (2014) only conducted an analysis of variables in Malaysia, in which, the results generated on the previous research might not be generalizable to the other countries. Theefore, current study attempted to uncover the relationship of the variables in Indonesia. This assumption was based on the fact that each country had different attitudes, behaviour, and characteristics. Furthermore, previous research by Mun (2014) also didn't clearly stated or explained on which industry became the focus on the research. Therefore, current study also attempted to fill this gap, in which, current study attempted to conduct the research only in the Indonesian cosmetics Industry. This model by Mun (2014) is then adapted to measure the relationship between variables on consumers in Indonesia, by only using four factors to suit the purpose of this research.

\section{Literature Review and Hypotheses}

\section{Product and green product}

"Product can be defined as everything both favorable and unfavorable, that a person receives in an exchange. A product may be a tangible good like a pair of shoes, a service like a haircut, an idea like "don't litter," or any combination of these three" (McDaniel et al., 2007). Product is a thing that a business gives to the consumer in exchange for other things that is beneficial to the business. Another explanation comes from Hawkins et al., (2007) which define product as anything that consumer acquire to fulfill their needs. Consumers sometimes bought products as an act in order to have fulfillment of satisfaction. Business that can satisfy consumers' needs can obtain huge resources or income that comes from consumer. Therefore, products have an important role in business activities.

Each product has its own unique features or attributes which can attract consumers to buy it. It can include style, packaging, color, size, and any other things that describe the product. This features or attributes are made based on the category of the product itself. McDaniel et al., (2007) classified product into two categories: (1) consumer products and (2) business products. A business product also called industrial product which consist of raw materials of goods/services to aid an organization needs to produce the product. While consumer product is a product that is bought to satisfy the consumer needs. Consumer products have other four categories consisting: (1) convenience product, (2) shopping product, (3) specialty product, and (4) unsought product.

Green product is defined as "one that has less of an environmental impact or is less detrimental to human health than the traditional product equivalent" (Speer, 2011). A rise in awareness of environmental problems, companies are starting to produce green products to anticipate natural depletion. Even though there is no product that is $100 \%$ "green", the usage of green product is still hoped to decrease environmental impact cause by the consumption or production of products which have a negative impact towards the environment. In order to produce a green product, company needs to fulfill several requirements needed to obtain the recognition. After they obtain the recognition, they are going to be labeled as an eco friendly product which is called eco-label. Global 
ecolabelling network (2016) defines eco-label as a sign which identify the product or services which is proven to have an environmentally preferable overall. Some famous international eco label would be coming from trusted institute such as ISO.

\section{Marketing and Green Marketing}

Marketing is a process which companies are creating values for consumers and build relationships in order to capture value from customers in return (Kotler \& Armstrong, 2013). It is one of the important actions needed by a company to promote their products or services to the consumers. According to Kerin et al., (2003), "marketing is the process of planning and executing the conception, pricing, promotion, and distribution of ideas, goods, and services to create exchanges that satisfy individual and organizational objectives". Marketing plays one of the vital roles in the business activities around the world. Marketing have many forms and types which is adapted to the situations exposed, however, it is important to plan the action before it started. Information and research is important before planning the strategic plan of the organization. A high analysis is needed in order to earn the organization goals and control over the situation.

Green marketing is producing and promoting reusable and eco-friendly products (Schiffman \& Wisenblit 2014). Rise in issues of global warming and climate change have appeal consumers' attention towards green products which are safe for a sustainable environment. Several studies have proven that people are starting to use eco-friendly products to reduce negative impact towards environment. "Green marketing consists of marketing products and services based on environmental factors or awareness. Companies involved in green marketing make decisions relating to the entire process of the company's products, such as methods of processing, packaging and distribution" (Investopedia, 2016).

\section{Purchase Behavior and Green Purchase Behavior}

"Consumer behavior is the study of consumers' actions during searching for, purchasing, using, evaluating, and disposing of products and services that they expect will satisfy their needs" (Schiffman \& Wisenblit, 2014). It consist of series of stages where consumer needs to decide what action need to be taken further after the process have been passed. There are three stages of decision making which consist of input stage, process stage, and output stage. Purchase behavior is a decision that is formed after post-decision activities in output stage (Schiffman \& Wisenblit, 2014). It is important because what a consumer done next is based on their choices in this stage. Purchase behavior will form a pattern on how consumer will purchase their products and marketers usually use predictive analytics in order to analyze the pattern.

Green purchase behavior is a part of green purchasing where it was formed after a green purchase intention appears as a motivational factor that affect the green purchase behavior (Joshi \& Rahman, 2015). In green purchase behavior, consumers are able and willing to purchase a green product which is environmentally friendly. Therefore, consumer should be aware first about the major problem concerning to the environment since knowledge determines the consumer reaction towards something. Green purchase behavior also can be referred to consumption of products that is beneficial for the environment conditions, can be reused or recycle, and it is sensitive against environmental problems (Lee, 2009). Products that have those characteristics can be categorized as a green product which has several advantages to the environment. Behavior towards the green product may changes depending on how consumer saw the urgencies of the problems. 


\section{Attitude Towards The Behavior}

"Attitude is a feeling or opinion about something or someone, or way of behaving that is caused by this" (Cambridge, 2016). An attitude was formed after the subject is exposed to the certain situation in which they must respond to the situation. "It is a learned predisposition to respond to an object or class of objects consistently favorable or unfavorable way" (Kerin et al., 2003). A consistent action of a person would change their behavior towards it.

Blackwell et al., (2006) explains that attitude towards the behavior is one of three types of attitudes where a person is have a favorable way toward a product but still have an unfavorable attitude to buy the product. Attitude almost plays a central role in consumer decision making and related marketing actions, which is also important to influence the behavior. Therefore, there are many researches are done in order to study an attitude of a consumer. Schiffman \& Wisenblit (2014) introduce a model called attitude-toward-behavior model that "captures the individual's attitude toward behaving or acting with respect to an object, rather than merely the person's attitude toward the object itself". According to them, this model will help people to understand consumers more compared to attitude-toward object model.

\section{Hypotheses}

Based on the literature above, this research would like to propose several hypotheses as follows:

H1: There is a positive influence of attitude towards the behavior on behavioral intention.

H2: There is a positive influence of perceived behavioral control on behavioral intention.

H3: There is a positive influence of perceived behavioral control on green purchase behavior.

H4: There is a positive influence of behavioral intention on green purchase behavior.

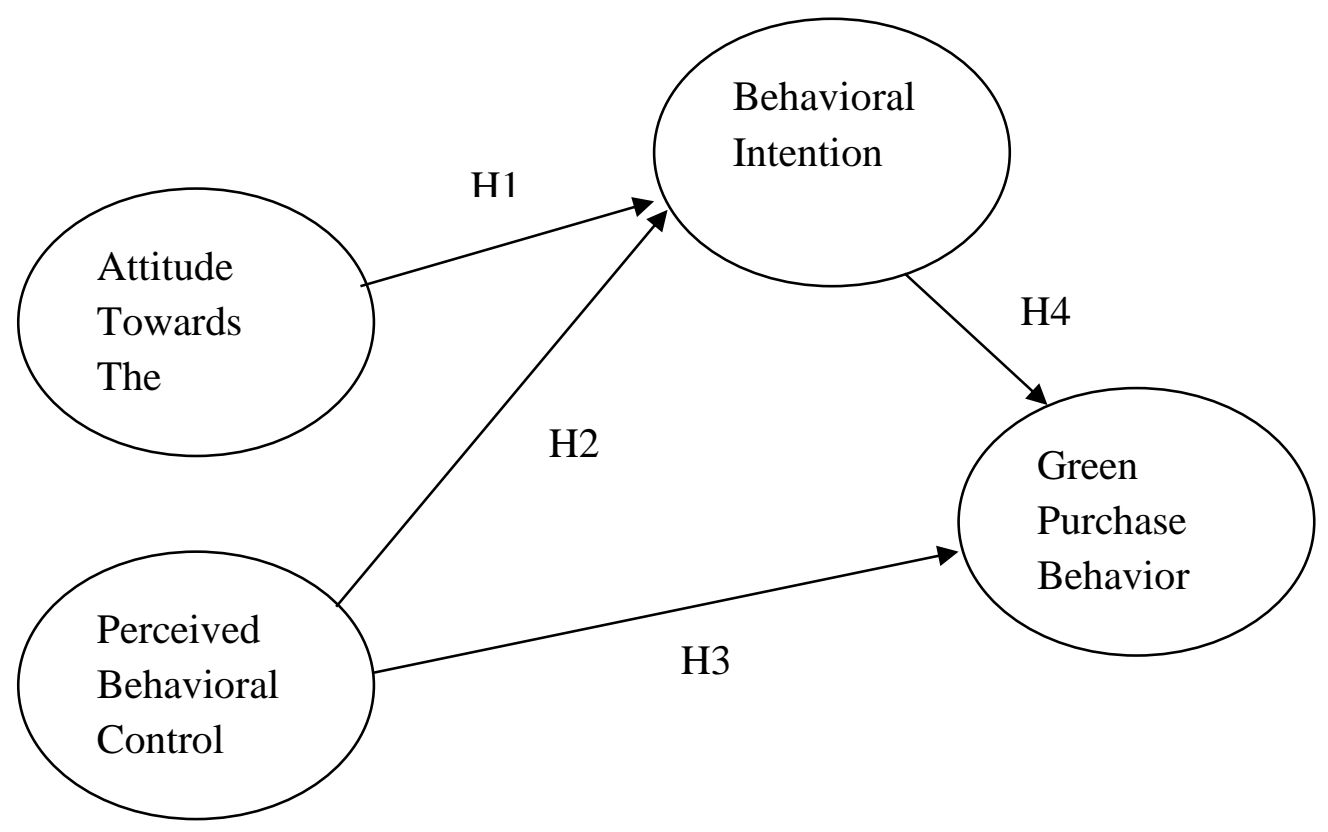


Figure 1. Research Model

\section{METHODS}

This research used survey method, in which questionnaires were used as instruments to collect the data from the respondents. A total of 260 respondents participated in this research, in which, data gathered from the respondents will further be analyzed using Structural Equation Modeling (SEM) method with the help of AMOS 22.0 software. Furthermore, this research using purposive sampling method as the sampling technique, since only those who've ever bought and used cosmetics products by The Body Shop were selected and chosen as the respondents.

Regarding the questionnaire used in this research, a five-points likert scale was used to measure respondent's level of agreement regarding the statements provided in the questionnaire. Respondent's response could range from " 1 " to " 5 ", in which " 1 " stand for "strongly disagree", " 2 " which stand for "disagree", "3" which stand for "neutral", "4" which stand for "agree", and " 5 " which stand for "strongly agree." Furthermore, a total of twenty four items measuring four variables were included in the questionnaire, in which 4 items measuring attitude toward the behavior were adapted from Kerin et al., (2003), 14 items measuring perceived behavioral control were adapted from Blackwell et al (2006), 3 items measuring behavioral intention were adapted from The Free Dictionary by Farlex (2016), and 3 items measuring green purchase behavior were adapted from Lee (2009).

Before the questionnaire was used in this research, a pretest on 50 respondents was conducted in order to ensure the validity, reliability, and the clarity of the items included on the questionnaire. After the pretest was conducted, the data were gathered and analyzed to ensure it's validity and reliability. After analyzing the data, it was confirmed that 8 items need to be omitted since it didn't fulfill the validity and reliability criteria. Items ATB1 and ATB4 which represent attitude toward behavior, and items $\mathrm{PBC} 1, \mathrm{PBC} 2, \mathrm{PBC} 3, \mathrm{PBC} 4, \mathrm{PBC} 5, \mathrm{PBC} 6, \mathrm{PBC} 7$, and $\mathrm{PBC} 8$ which represent perceived behavioral control were deleted. Then, the data was re-analyzed, and it was revealed that the rest of the items and variable had fulfilled the validity and reliability criteria. Therefore, the rest of the items were used in the research.

Before the data were analyzed in order to test the hypotheses, a measurement model analysis using confirmatory factor analysis (CFA) needed to be conducted beforehand in order to test that the model had fulfilled the goodness of fit criteria. After assessing the model, it was revealed that the model had fulfilled the goodness-of-fit (GoF) criteria with the results was shown as follows. 
Table 1. Goodness-of-Fit (GoF) Test Results

\begin{tabular}{|c|c|c|c|}
\hline Criteria & $\begin{array}{c}\text { Critical } \\
\text { Point }\end{array}$ & Analysis Result & $\begin{array}{c}\text { Model } \\
\text { Evaluation } \\
\text { Acceptable }\end{array}$ \\
\hline GFI & $\geq 0.90$ & 0.910 & Marginal Fit \\
\hline AGFI & $\geq 0.90$ & 0.868 & Conservative \\
\hline RMSEA & $\leq 0.08$ & 0.079 & Marginal Fit \\
\hline NFI & $\geq 0.90$ & 0.878 & Good model fit \\
\hline CFI & $\geq 0.90$ & 0.920 & \\
\hline
\end{tabular}

\section{RESULTS AND DISCUSSION}

\section{Result}

First of all, multicolinearity assessment need to be conducted in order to found out the covariance determinant matrix that indicates the multicolinearity. In this software, it will give a direct warning if the covariance matrix shows singularity or multicolinearity. In this research, the data analysis from AMOS 22.0 software didn't show any warning about the indication of multicolinearity itself. Therefore, it could be concluded that data used in this research didn't have multicolinearity problem.

After conducting the measurement model assessment, the data were further examined in order to assess the relationship between variables. The result of the structural model assessment were shown on table 2 , and 3 respectively.

Table 2. Discriminant Validity Analysis

\begin{tabular}{|c|c|c|c|c|}
\hline & ATB & PBC & BI & GPB \\
\hline ATB & $\mathbf{0 . 8 7 0}$ & & & \\
\hline PBC & 0.437 & $\mathbf{0 . 7 1 2}$ & & \\
\hline BI & 0.512 & 0.356 & $\mathbf{0 . 7 8 0}$ & \\
\hline GPB & 0.415 & 0.602 & 0.216 & $\mathbf{0 . 6 9 6}$ \\
\hline
\end{tabular}


Table 3. AVE, composite reliability, and factor loadings

\begin{tabular}{|c|c|c|c|c|}
\hline Construct & Indicators & $\begin{array}{c}\text { Factor } \\
\text { Loading }\end{array}$ & $\begin{array}{c}\text { Variance } \\
\text { Extracted }\end{array}$ & $\begin{array}{l}\text { Construct } \\
\text { Reliability } \\
\end{array}$ \\
\hline \multirow{2}{*}{$\begin{array}{l}\text { Attitude Towards } \\
\text { The Behavior }\end{array}$} & ATB2 & 0.837 & \multirow{2}{*}{0.757} & \multirow{2}{*}{0.862} \\
\hline & ATB3 & 0.902 & & \\
\hline \multirow{6}{*}{$\begin{array}{c}\text { Perceived } \\
\text { Behavioral Control }\end{array}$} & PBC9 & 0.704 & \multirow{6}{*}{0.650} & \multirow{6}{*}{0.824} \\
\hline & PBC10 & 0.633 & & \\
\hline & PBC11 & 0.707 & & \\
\hline & PBC12 & 0.721 & & \\
\hline & $\mathrm{PBC} 13$ & 0.840 & & \\
\hline & PBC14 & 0.725 & & \\
\hline \multirow{3}{*}{ Buying Intention } & BI1 & 0.765 & \multirow{3}{*}{0.608} & \multirow{3}{*}{0.823} \\
\hline & BI2 & 0.804 & & \\
\hline & $\mathrm{BI} 3$ & 0.770 & & \\
\hline \multirow{3}{*}{$\begin{array}{l}\text { Green Purchase } \\
\text { Behavior }\end{array}$} & GPB1 & 0.803 & \multirow{3}{*}{0.685} & \multirow{3}{*}{0.733} \\
\hline & GPB2 & 0.720 & & \\
\hline & GPB3 & 0.739 & & \\
\hline
\end{tabular}

Based on the results shown on table 2, 3, and 4, it was revealed that the model had fulfilled the composite reliability, AVE, factor loadings, and discriminant validity criteria. In terms of these criterias, Hair et al., (2010) had stated that a good AVE score must be 0.50 or above, factor loading must be equal or more than 0.50 , construct reliability should be greater than 0.70 . Furthermore, to fulfill the discriminant validity criteria, the root square of AVE should be higher than the correlation between the variable and other variable.

Furthermore, the hypotheses proposed in this research were tested and analyzed in order to determine whether the hypotheses were supported or rejected. The result of the hypotheses testing were shown on table 4 . Regarding the criteria used to determine whether to support or reject the hypotheses, this research used 5\% significant level (Lind et al., 2012). Furthermore, this research used one-tail test to test the hypotheses. In this case, If the $\mathrm{p}$-value $\leq 0.05$, the hypothesis is supported. In the contrary, if the p-value $\geq 0.05$ the hypothesis was rejected. 
Table 4. Hypotheses Testing Results

\begin{tabular}{|c|c|c|c|}
\hline Hypotheses & Path & P-value & $\begin{array}{c}\text { Hypothesis } \\
\text { analysis }\end{array}$ \\
\hline $\begin{array}{c}\text { H1: There is a positive influence of attitude } \\
\text { towards the behavior on behavioral intention. }\end{array}$ & BI <--- ATB & $* * *$ & Supported \\
\hline $\begin{array}{c}\text { H2: There is a positive influence of } \\
\text { perceived behavioral control on behavioral } \\
\text { intention. }\end{array}$ & BI <--- PBC & 0.045 & Supported \\
\hline $\begin{array}{c}\text { H3: There is a positive influence of } \\
\text { perceived behavioral control on green } \\
\text { purchase behavior }\end{array}$ & GPB <--- PBC & $* * *$ & Supported \\
\hline $\begin{array}{c}\text { H4: There is a positive influence of } \\
\text { behavioral intention on green purchase } \\
\text { behavior. }\end{array}$ & GPB <--- BI & 0.838 & $\begin{array}{c}\text { Not } \\
\text { Supported }\end{array}$ \\
\hline
\end{tabular}

Based on the table above, it could be stated that the only construct that is not significant is the relationship between behavioral intention and green purchase behavior. To analyze the insignificant construct, the first thing that was done is to compare the result with the previous research which examined the same variables and model. H1 proposed that there's a positive influence of attitude towards the behavior on behavioral intention. Based on the result, it was shown that the p-value of the influence of attitude towards the behavior on behavioral intention is "****" which indicate that the p-value is below 0.05 . Therefore, it can be concluded that there is a positive influence of attitude towards the behavior on behavioral intention. $\mathrm{H} 2$ proposed that there's a positive influence of perceived behavioral control on behavioral intention. Based on the result, it was revealed that shows the $\mathrm{p}$-value of the influence of perceived behavioral control on behavioral intention is " 0.045 " which means that the p-value is below 0.05 . Therefore, it can be concluded that there is a positive influence of perceived behavioral control on behavioral intention. $\mathrm{H} 3$ hypothesized that there's a positive influence of perceived behavioral control on green purchase behavior. Based on the result, it could be concluded that the p-value of the influence of perceived behavioral control on green purchase behavior is "***" which means that the p-value is below 0.05 . Therefore, it can be concluded that there is a positive influence of perceived behavioral control on green purchase behavior. Lastly, $\mathrm{H} 4$ hypothesized that there's a positive influence of behavioral intention on green purchase behavior. Based on the results, it could be concluded that the p-value of the influence of behavioral intention on green purchase behavior is " 0.838 " which means that the p-value is above 0.05 . Therefore, it can be concluded that there is no positive influence of behavioral intention on green purchase behavior.

\section{Discussion}

Based on the hypotheses testing result, it could be concluded that out of four tested hypothesis, there are three which are supported and one who is not supported.

The first hypothesis states that there is a positive influence of attitude towards the behavior on behavioral intention. This statement is supported by another research from Kuo \& Yen (2008) which shows that attitude had a significantly positive effect on behavioral intention to use $3 \mathrm{G}$ 
mobile value-added services. Another research from Kim et al., (2013) also shows that there is a support in the significant relationship between attitude towards the behavior and behavioral intention. This indicates that there is a positive influence of attitude towards the behavior on behavioral intention.

Among the indicator used to measure the attitude towards the behavior, indicator ATB3 shows the highest factor loading. ATB3 statement is "It is very important to raise environmental awareness among people in Karawaci/Tangerang". From this statement it can be concluded that respondent are not only aware about the environmental problem, but there are some intention to behave according to the problem which is to raise people awareness in Karawaci/Tangerang. Other than the sales of products, green cosmetic product also needs to raise public awareness about the environmental problem which is in line with the respondent from Karawaci/Tangerang.

The second hypothesis states that there is a positive influence of perceived behavioral control on behavioral intention. Another research from Kim et al., (2013) explains that there is a significant relationship between the perceived behavioral control and the behavioral intention to read menu labels. Perceived behavioral control does have a positive influence including in this research. Furthermore, PBC11 earn the highest average number among other indicators. The statement is "I think if I carry out some pro-environmental behavior in my everyday life, I would contribute a lot to our environment". From the statement it can be concluded that there is an intention comes where respondent believe that if they carry out some pro-environmental behavior in my everyday life, they can contribute to the environment. The focus to the environment made them to have intention to have a pro-environmental problem which can bring out the behavioral intention towards the environment. There is a possibility if respondent understand that by using green cosmetic product will contribute to the environment, respondent may change their behavior towards the green cosmetic product.

The third hypothesis states that there is a positive influence of perceived behavioral control on green purchase behavior. Previous research by Mun (2014) shows that the perceived environmental responsibility, perceive seriousness of environmental problems, and perceived effectiveness of environmental behavior are having a significant relationship with the green purchase behavior. This research obtains the same result with the previous research.

Perceived behavioral control have a direct effect to the green purchase behavior corresponds to the research model. The relation between perceived behavioral control and green purchase behavior gets the highest estimates on the factor loading of standardized regression weights among the other relationship. This means that the perceived behavioral control have a highest significant of relationship compared to other variables. It also earns the highest estimates on the regression weights table which shows that they have a stronger relationship among other variables. Indicator PBC13 with statement "If I engage in some pro-environmental behavior, the environmental quality of Karawaci/Tangerang will be improved" earn the highest construct reliability point which explains that it is more reliable compared to other variable. Respondent believe that small acts could contribute to the environment of Karawaci/Tangerang. That's one of the reason the respondent gave through their answer from questionnaire given. If the consumer aware that by using green cosmetic product could contribute to environment, there could be a chance where consumer will start to use green cosmetic product itself. 
The fourth hypothesis states that there is a positive influence of behavioral intention on green purchase behavior. This hypothesis is not supported because it's p-value is above 0.05 in this research. This result is similar to other research from De Cannière (2009) where behavioral intention is a weak predictor towards a behavior. Most of the researches use the behavioral intention as a mediating variable and at the same time, this model fails to predict the behavior and tends to show a low correlation with the behavior itself.

From the questionnaire given to the respondent, respondent were asked if what could prevent them to purchase green cosmetic product. Most of the respondent answer "expensive price" as the top reason why it prevent them from purchasing the green cosmetic product. By referring to the descriptive analysis of GPB indicators, it is also supported that even tough consumes believe that from using green cosmetic product and they choose green cosmetic product rather than the nongreen ones if the quality are similar, the indicator GPB 3 which state that "I buy green cosmetic product even if they are more expensive than the non-green ones" shows that price is one of the important factors that determine the behavior for consumers in Karawaci/Tangerang. However, because this study focuses on internal factors, price will not be discussed further.

\section{CONCLUSIONS AND IMPLICATIONS Conclusions}

Based on the findings in this research, it could be concluded that there is a positive influence of attitude towards the behavior and perceived behavioral control on behavioral intention. Attitude towards the behavior tends to brings out intention to behave according to the attitude itself. Therefore, attitude towards the behavior must be encouraged more to the consumers. Furthermore, consumer beliefs will also unconsciously drive and strengthen them to have such specific behavior. Moreover, it was revealed that there's also a positive influence of perceived behavioral control on green purchase behavior. According to the theory of planned behavior, perceived behavioral control can affect both behavioral intention and green purchase behavior. This means perceived behavioral control has a strong effect towards green purchase behavior in Karawaci/Tangerang. However, this research also found that there is no positive influence of behavioral intention on green purchase behavior.

Previous research by Mun (2014) had analyzed the relationship between attitude toward behavior and perceived behavioral control toward green purchase decision. However, this research attempted to develop the model by also analyzing the effect of attitude toward behavior and perceived behavioral control toward green purchase decision through behavioral intention. This research attempted to fill this gap. Furthermore, this research attempted to generalize the model and the relationship between variables, in which this research was conducted in Indonesia while previous research was conducted in Malaysia. Furthermore, this research attempt to investigate the effect of variables toward Indonesian green cosmetics consumers, while previous research attempted to examine the relationship between variables on the Malaysian green products consumers. In this case, different country and different city may also resulted in a different culture of the individuals which could also indicate that there's a difference in attitude of the consumers.

\section{Managerial implications}

First of all, company, particularly Asia-Pacific company which business is in the cosmetics industry should understand that attitude toward the behavior has an important role in determining the behavioral intention. Company can encourage more consumers to have an intention in behaving 
towards a green cosmetic product by increasing the certification towards the environment. This is a proof that a company had a supportive attitude towards the environmental activity which can be transferred to the consumers. Second, the green cosmetic product company also has to encourage the usage of green cosmetic product to persuade and convince the consumer that by using green cosmetic product, they already contribute to the environment. Company can make an agreement to the environmental activist or company which strengthen the position of the producer that they supports the environmental activity itself.

\section{Limitations and suggestions}

Despite had filled in the gap left by the previous research, this research wasn't free from limitations. First of all, there are only three variables that are investigated to find out the green purchase behavior while there are many other factors that could contribute to green purchase behavior based on consumer behavior theory. Further research might added another variable which could increase the generalizability of the findings. Second, this research was conducted in Indonesia, which might limit the generalizability of the research. Therefore, further research was encouraged in order to increase the variability and the generalizability of the results. Which are still can be expanded to represent the Indonesian consumer. Furthermore, further research should examine the relationship between variables in the other industry in order to increase he generalizability of the findings.

\section{REFERENCES}

Ajzen, I. (2015). Consumer attitudes and behavior: The theory of planned behavior applied to food consumption decisions. Rivista Di Economia Agraria, 2, 121-138. Retrieved July 29, 2016, from www.fupress.net/index.php/rea/issue/download/1246/20

Arnould, E. J., Price, L. L., and Zinkhan, G. M. (2005). Consumers (2nd ed., International Edition). New York: McGraw-Hill/Irwin.

Behavioural Intention. (n.d.). In The Free Dictionary by Farlex. Retrieved July 29, 2016, from http://medical-dictionary.thefreedictionary.com/behavioural intention

Blackwell, R. D., Miniard, P. W., \& Engel, J. F. (2006). Consumer behavior (10th ed., International Student Edition). Thomson South-Western.

De Cannière, M. H., Pelsmacker, P. D., \& Geuens, M. (2009, January 1). Relationship quality and the theory of planned behavior models of behavioral intentions and purchase behavior. Journal of Business Research, 62(1), 82-92. Retrieved July 31, 2016, from http://www.sciencedirect.com/science/article/pii/S0148296308000027

Green Marketing. (n.d.). Retrieved July 28, 2016, from http://www.investopedia.com/terms/g/green-marketing.asp

Hair, J. F., Jr., Black, W. V., Babin, B. J., and Anderson, R. E. (2010). Multivariate data analysis: A global perspective (7th ed.). New Jersey: Pearson Prentice Hall.

Hawkins, D. I., Mothersbaugh, D. L., and Best, R. J. (2007). Consumer Behavior: Building Marketing Strategy (10th ed., McGRAW-HILL INTERNATIONAL EDITION). New York: McGraw-Hill/Irwin.

Joshi, Y., and Rahman, Z. (2015, February 7). Factors Affecting Green Purchase Behaviour and Future Research Directions. International Strategic Management Review, 3(1-2), 128-143. doi:doi:10.1016/j.ism.2015.04.001 
Kerin, R. A., Berkowitz, E. N., Hartley, S. W., and Rudelius, W. (2003). Marketing (7th ed., International Edition). New York: McGraw-Hill/Irwin.

Kim, E., Ham, S., Yang, I. S., and Choi, J. G. (2013, December). The roles of attitude, subjective norm, and perceived behavioral control in the formation of consumers' behavioral intentions to read menu labels in the restaurant industry. International Journal of Hospitality Management, Vol. 35, 203-213.

Kotler, P., and Armstrong, G. (2013). Principles of marketing (15th ed., Global Edition). New York: Pearson.

Kuo, Y. F., and Yen, S. N. (2009). Towards an understanding of the behavioral intention to use 3G mobile value-added services. Computers in Human Behavior, 103-110.

Lee, K. (2009). Gender differences in Hong Kong adolescent consumers' green purchasing behavior. Journal of Consumer Marketing, 26 (2), 87-96.

Lind, D. A., Marchal, W. G., and Wathen, S. A. (2012). Statistical techniques in business \& economics (15th ed.). New York: McGraw-Hill/Irwin.

Mun, T. S. (2014). Factors that influence green purchase behaviour of malaysian consumers, Thesis : Universiti Tunku Abdul Rahman.

Schermerhorn, J. R., Jr. (2013). Introduction to management (12th ed., International Student Version). John Wiley \& Sons Singapore Pte.

Schiffman, L. G., and Wisenblit, J. L. (2014). Consumer behaviour (11th ed.). Pearson.

Speer, M. (2011, December 9). What is a Green Product? Retrieved July 28, 2016, from http://www.isustainableearth.com/green-products/what-is-a-green-product 